\title{
Fine Tuning of MLCT States in New Mononuclear Complexes of Ruthenium(II) Containing Tris(1-pyrazolyl)methane, 2,2'-Bipyridine and Aromatic Nitrogen Heterocycles
}

\author{
Néstor E. Katz, ${ }^{*[a]}$ Isabel Romero, ${ }^{[b]}$ Antoni Llobet, ${ }^{*[b]}$ Teodor Parella, ${ }^{[c]}$ and \\ Jordi Benet-Buchholz ${ }^{[\mathrm{d}]}$
}

Keywords: Charge transfer / Ruthenium / N ligands / Scorpionate ligands

The syntheses of new mononuclear ruthenium(II) complexes of the type: $[\mathrm{Ru}(\mathrm{bpy})(\mathrm{L})(\mathrm{tpm})]\left(\mathrm{PF}_{6}\right)_{2}$ \{tpm = tris(1-pyrazolyl)methane; bpy $=2,2^{\prime}$-bipyridine; $\mathrm{L}=$ pz (pyrazine; 1 ), 4,4'-bpy (4,4'-bipyridine; 2$)$, and bpe [trans-1,2-bis(4-pyridyl)ethylene; 3]\} are described, together with their spectroscopic, electrochemical, and photophysical properties. A complete assignment of the NMR resonances of the three species could be made in $\mathrm{CD}_{3} \mathrm{CN}$ by bidimensional techniques. A fine tuning of the energies of MLCT (metal-to-ligand charge transfer) states in these complexes is disclosed when comparing, in $\mathrm{CH}_{3} \mathrm{CN}$, the values of their maximum absorption wavelengths for the most intense visible bands $\left(\lambda_{\max }\right)$ and their redox potentials for the $\mathrm{Ru}{ }^{\mathrm{III}} / \mathrm{Ru}^{\mathrm{II}}$ couples; this effect, relevant to the design of efficient photocatalysts, can be attributed to a decreasing order of $\mathrm{d}_{\pi}(\mathrm{Ru}) \rightarrow \pi^{*}\left(2,2^{\prime}\right.$-bpy $)$ backbonding when decreasing the distance between both $\mathrm{N}$ atoms in the aromatic nitrogen heterocycle $\mathrm{L}$ that acts in a monodentate manner. Only the species with $\mathrm{L}=$ bpe emits at room temperature, pointing to the conclusion that MLCT excited states in this series become higher in energy than dd excited states when the value of $\lambda_{\max }$ is lower than $400 \mathrm{~nm}$. These species are also useful building blocks for new dinuclear mixed-valent complexes.

(ㄷ Wiley-VCH Verlag GmbH \& Co. KGaA, 69451 Weinheim, Germany, 2005)

\section{Introduction}

Polypyridylruthenium(II) complexes represent a keystone in the development of photochemistry and electron- and energy-transfer disciplines, ${ }^{[1]}$ and, among other applications, have led to the design of molecular electronic devices, ${ }^{[2]}$ including wires and switches. ${ }^{[3]}$ Furthermore, polypyridylruthenium(II) complexes are often used as building blocks for the development of macromolecular assemblies of interest in biochemistry and clinical diagnosis, ${ }^{[4]}$ as well as for the design of molecular machines. ${ }^{[5]}$ In most of these areas, the synthetic strategy followed to obtain the desired compounds is by $\mathrm{Ru}^{\mathrm{II}}$ substitution chemistry. ${ }^{[6]}$ Unfortu-

[a] Instituto de Química Física, Facultad de Bioquímica, Química y Farmacia, Universidad Nacional de Tucumán,

Ayacucho 491, T4000INI San Miguel de Tucumán, Argentina

E-mail: nkatz@arnet.com.ar

[b] Departament de Química, Universitat de Girona,

Campus de Montilivi, 17071 Girona, Spain

Fax: + 34 972-41-81-50

E-mail: antoni.llobet@udg.es

[c] Servei de RMN, Universitat Autònoma de Barcelona,

Bellaterra 08193, Barcelona, Spain

Fax: + 34 93-581-22-91

E-mail: teodor.parella@uab.es

[d] Bayer Industry Services SUA-SPA X-ray Laboratory, Geb. Q18, Raum 490, Bayer AG,

51368 Leverkusen, Germany

E-mail: jbenet@iciq.es

Supporting information for this article is available on the WWW under http://www.eurjic.org or from the author. nately, full mechanistic studies on these reactions are scarce and, in many cases, incomplete. ${ }^{[7]}$ As a result of these two factors, it is of primary importance to understand and control the electronic and steric factors exerted by different types of ligands in order to properly monitor their substitution processes.

Ruthenium(II) complexes of the type $[\mathrm{Ru}(\mathrm{bpy})(\mathrm{L})(\mathrm{tpm})]^{2+}$ with the tripodal ligand tpm [tris(1pyrazolyl)methane], the bidentate ligand bpy $\left(2,2^{\prime}\right.$-bipyridine), and monodentate ligands $\mathrm{L}\left(\mathrm{Cl}^{-}, \mathrm{H}_{2} \mathrm{O}, \mathrm{O}^{2-}\right.$ or py) are well known. ${ }^{[8,9]}$ A coarse control of MLCT (metal-toligand charge transfer) excited states can be achieved by changing substituents in the $4,4^{\prime}$-positions of bpy. ${ }^{[9-11]}$ In this work, we report on the fine tuning of the energies of $\mathrm{d}_{\pi}(\mathrm{Ru}) \rightarrow \pi^{*}$ (bpy) MLCT states introduced by changing the nature of the ligand $\mathrm{L}$ in $[\mathrm{Ru}(\mathrm{bpy})(\mathrm{L})(\mathrm{tpm})]^{2+}$ complexes with $\mathrm{L}=\mathrm{pz}$ (pyrazine), 4,4'-bpy (4,4'-bipyridine), and bpe [trans-1,2-bis(4-pyridyl)ethylene]. These changes can be compared to the variations observed in the analogous series $[\mathrm{Ru}(\mathrm{bpy})(\mathrm{L})(\text { trpy })]^{2+}\left(\operatorname{trpy}=2,2^{\prime}: 6^{\prime}, 2^{\prime \prime}{ }^{\prime}\right.$ terpyridine),${ }^{[12-16]}$ and can be related to the electronic and structural variations induced when going from a meridional (trpy) to a facial (tpm) coordination. ${ }^{[17]}$ The control of MLCT excited sates is relevant in photocatalysis, as demonstrated by the extensive literature concerning artificial photosynthesis based on transition-metal complexes. ${ }^{[18-22]}$ On the other hand, scorpionate ligands, like tpm, can be 
used for obtaining luminescent supramolecular complexes. ${ }^{[23]}$ The new complexes studied here are also useful building blocks for new, dinuclear, mixed-valent species, some of which will be reported in a subsequent paper. The structures of the ligands are shown in Scheme 1.<smiles></smiles><smiles>c1cnccn1</smiles><smiles>c1ccc(-c2ccccn2)nc1</smiles><smiles>c1cc(-c2ccncc2)ccn1</smiles>
$\mathrm{pz}$<smiles>F/C=C(/F)c1ccncc1</smiles>

Scheme 1

\section{Results and Discussion}

\section{Synthesis and Solid-State Structures}

The synthetic procedures followed to obtain complexes 1-3 are straightforward and involve the substitution of the anionic $\mathrm{Cl}^{-}$ligand in the complex $\left[\mathrm{Ru}^{\mathrm{II}} \mathrm{Cl}(\mathrm{bpy})(\mathrm{tpm})\right]^{+}$by the desired monodentate ligand L (pz, 4,4'-bpy or bpe), as shown below.

$$
\left[\mathrm{Ru}^{\mathrm{II}} \mathrm{Cl}(\mathrm{tpm})(\mathrm{bpy})\right]^{+}+\mathrm{L} \underset{\text { reflux }}{\stackrel{\mathrm{MeOH} / \mathrm{H}_{2} \mathrm{O}}{\longrightarrow}}\left[\mathrm{Ru}^{\mathrm{II}}(\mathrm{L})(\mathrm{tpm})(\mathrm{bpy})\right]^{2+}+\mathrm{Cl}^{-}
$$

The crystal structure of complex 1 was solved by means of a single-crystal X-ray diffraction analysis. Figure 1 shows the ORTEP diagram of the molecule along with the corresponding labeling scheme. The Ru center adopts a pseudooctahedral type of geometry with three $\mathrm{N}$ atoms $(\mathrm{N} 1, \mathrm{~N} 3$, $\mathrm{N} 5$ ) from the tpm ligand coordinated in a facial fashion. Two other positions are occupied by the 2,2'-bpy ligand (N7, N8), which acts in chelate manner, while the sixth one is occupied by the nitrogen atom, N9, of the monodentate $\mathrm{pz}$ ligand. The $\mathrm{Ru}-\mathrm{N}$ bond lengths are within the range found for similar complexes previously described in the literature. ${ }^{[24,25]}$ The bonding angles are also within the ranges found in the literature ${ }^{[24,25]}$ and reflect the nature of the different ligands.

Complex 1 has a local pseudo- $C_{m}$ symmetry with the mirror plane located in the plane formed by the pyrazine ring and the pyrazolyl group of tmp trans to the pyrazine. This symmetry is slightly disturbed by a $4.3^{\circ}$ rotation of the bpy out of the mirror plane. The local $C_{m}$ symmetry of the molecule is broken by the location of the anions in the crystal packing. These are arranged around the complex and

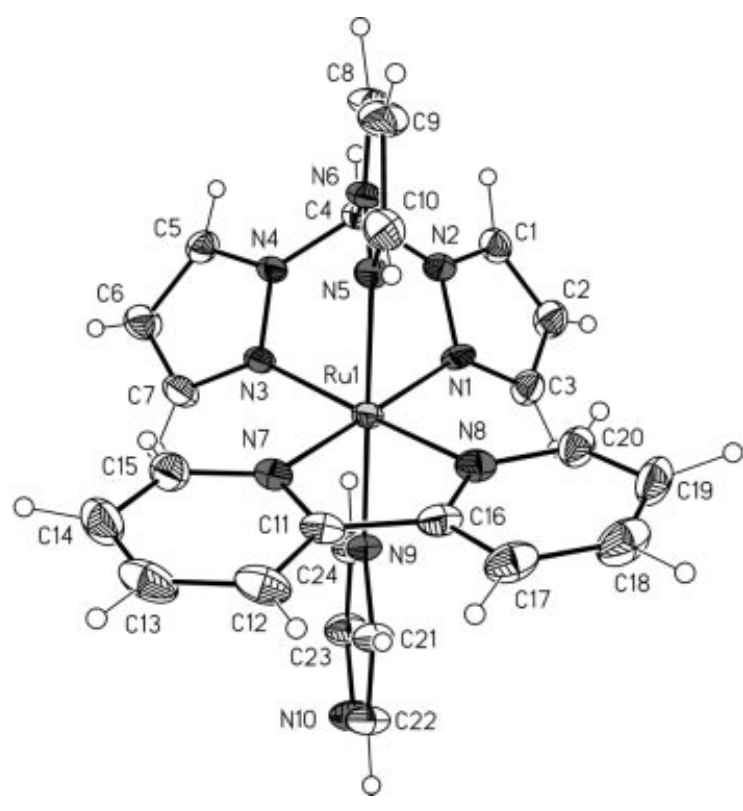

Figure 1. ORTEP plot (ellipsoids drawn at 50\% probability) of the cationic moiety of complex 1 together with its labeling scheme; selected bond lengths $[\mathrm{A}]$ and angles $\left[{ }^{\circ}\right]$ : $\mathrm{Ru}(1)-\mathrm{N}(1)$ 2.082(2), $\mathrm{Ru}(1)-\mathrm{N}(3)$ 2.083(3), Ru(1)-N(5) 2.060(2), Ru(1)-N(7) 2.049(2), $\mathrm{Ru}(1)-\mathrm{N}(8) 2.049(3), \mathrm{Ru}(1)-\mathrm{N}(9) \quad 2.079(2) ; \mathrm{N}(1)-\mathrm{Ru}(1)-\mathrm{N}(3)$ $83.13(16), \quad \mathrm{N}(1)-\mathrm{Ru}(1)-\mathrm{N}(5) \quad 85.95(9), \quad \mathrm{N}(5)-\mathrm{Ru}(1)-\mathrm{N}(3)$ $86.80(15), \quad \mathrm{N}(7)-\mathrm{Ru}(1)-\mathrm{N}(8) \quad 79.04(18), \quad \mathrm{N}(1)-\mathrm{Ru}(1)-\mathrm{N}(8)$ $99.69(17), \quad \mathrm{N}(5)-\mathrm{Ru}(1)-\mathrm{N}(8) \quad 89.13(16), \quad \mathrm{N}(5)-\mathrm{Ru}(1)-\mathrm{N}(7)$ $92.54(9), \quad \mathrm{N}(3)-\mathrm{Ru}(1)-\mathrm{N}(7) \quad 98.02(17), \quad \mathrm{N}(7)-\mathrm{Ru}(1)-\mathrm{N}(9)$ $90.18(9), \quad \mathrm{N}(8)-\mathrm{Ru}(1)-\mathrm{N}(9) \quad 92.91(15), \quad \mathrm{N}(9)-\mathrm{Ru}(1)-\mathrm{N}(1)$ 91.35(9), $\quad \mathrm{N}(9)-\mathrm{Ru}(1)-\mathrm{N}(3) \quad 91.28(14), \quad \mathrm{N}(1)-\mathrm{Ru}(1)-\mathrm{N}(7)$ 178.06(17), $\quad \mathrm{N}(3)-\mathrm{Ru}(1)-\mathrm{N}(8) \quad 174.88(13), \quad \mathrm{N}(5)-\mathrm{Ru}(1)-\mathrm{N}(9)$ $176.86(13)$

together they form a one-dimensional $2_{1}$ screw axis which gives the chirality to the crystal.

\section{Spectroscopic and Redox Properties}

Complexes of the type $[\mathrm{Ru}(\mathrm{bpy})(\mathrm{L})(\mathrm{tpm})]^{2+}$ are well known in relation to catalysis. ${ }^{[8]}$ However, the influence of slight variations in the structure of the ligands $\mathrm{L}$ on the spectral, electrochemical, and photophysical properties of these species has not been much studied; besides, there are no examples so far of mixed-valent species that incorporate tpm in their coordination sphere. As noted before, ${ }^{[9]}$ the simplification introduced by having a poor $\pi$-backbonding ligand such as tpm would, in principle, disclose the role of the chromophoric ligands in controlling the spectroscopic, electrochemical, and photophysical properties of MLCT excited states.

\section{NMR Spectroscopy}

Figure 2 shows the aromatic region of the ${ }^{1} \mathrm{H}$ NMR spectrum of complex $\mathbf{1}$ in $[\mathrm{D}]_{3}$ acetonitrile, as a representative example; the COSY, NOESY and HSQC spectra together with all the NMR spectra for complexes $\mathbf{2}$ and $\mathbf{3}$ are provided as Supporting Information. The spectra can be unambiguously assigned thanks to molecular symmetry, the smaller coupling constants of five-membered pyrazolyl rings with regard to six-membered pyridyl and pyrazinyl 
rings, and with the aid of 2D NMR spectra. The symmetry lost in the solid state is recovered in solution and thus the two pyrazolyl rings cis to the pyrazine ligand become magnetically equivalent, as do the pyridyl moieties of bpy. Two intraligand NOE effects are observed for tpm between $\mathrm{H} 4$ and $\mathrm{H} 1$ and $\mathrm{H} 8$, together with a third interligand NOE between $\mathrm{H} 3$ of tpm and $\mathrm{H} 20$ of bpy $\left(\mathrm{d}_{\mathrm{H} 3-\mathrm{H} 20}=2.46 \AA\right)$; the latter is a key feature that allows us to assign the NMR resonances with total confidence. The pyrazine and the other ligands acting in a monodentate fashion - 4,4'-bpy and bpe - lose their symmetry upon coordination, a fact that is clearly manifested in their NMR spectra.

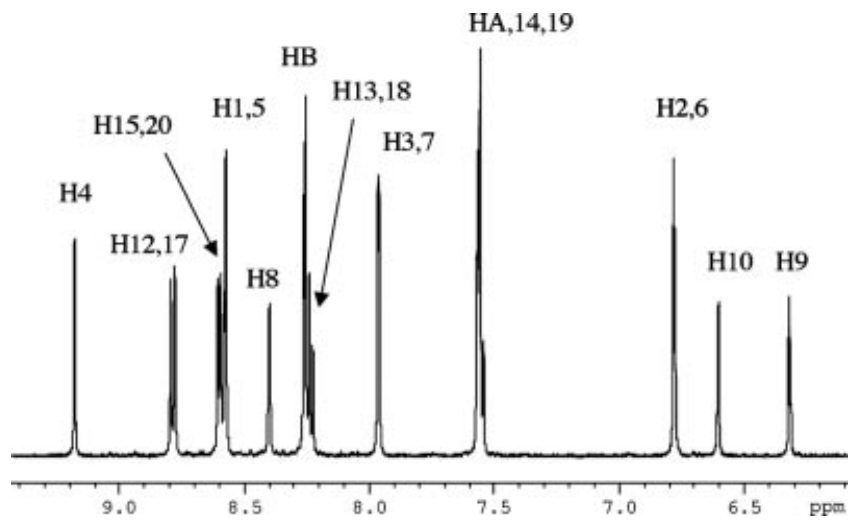

Figure 2. ${ }^{1} \mathrm{H}$ NMR spectrum showing the aromatic region of $[\mathrm{Ru}(\mathrm{bpy})(\mathrm{pz})(\mathrm{tpm})]^{2+}$ in $\mathrm{CD}_{3} \mathrm{CN}$

\section{UVIVis Spectra}

Table 1 shows the UV/Vis spectroscopic data of the three new complexes in $\mathrm{CH}_{3} \mathrm{CN}$ together with that of $[\mathrm{Ru}(\mathrm{bpy})(\mathrm{py})(\mathrm{tpm})]^{2+}$ for comparison purposes. Figure 3 shows the electronic spectrum of complex $\mathbf{1}$, as a representative example. Bands between 200 and $300 \mathrm{~nm}$ are assigned to the $\pi-\pi^{*}$ transitions of tpm and bpy. ${ }^{[9]}$ In the visible region, characteristic bands of $\mathrm{d}_{\pi}(\mathrm{Ru}) \rightarrow \pi^{*}\left(2,2^{\prime}\right.$-bpy $)$ and $\mathrm{d}_{\pi}(\mathrm{Ru}) \rightarrow \pi^{*}(\mathrm{~L})$ MLCT transitions are observed. Gaussian deconvolution of the spectrum of $\mathbf{1}$ (see Supporting Information) allows the assignment of the bands at 457 and $392 \mathrm{~nm}$ to the former MLCT, while the intermediate one at $418 \mathrm{~nm}$ corresponds to the latter MLCT. When the deconvoluted maxima of the $\mathrm{d}_{\pi}(\mathrm{Ru}) \rightarrow \pi^{*}\left(2,2^{\prime}\right.$-bpy $)$ MLCT bands are compared in the series, a decreasing order of energies of the MLCT excited states is disclosed as follows: $[\mathrm{Ru}(\mathrm{bpy})(\mathrm{pz})(\mathrm{tpm})]^{2+}>\left[\mathrm{Ru}\left(4,4^{\prime} \text {-bpy }\right)(\mathrm{bpy})(\mathrm{tpm})\right]^{2+}>[\mathrm{Ru}-$ (bpe)(bpy)(tpm) $]^{2+}$.

This fine tuning is consistent with the backbonding capabilities of the L ligands. As the second (uncoordinated) nitrogen of the aromatic heterocycle $\mathrm{L}$ is further away from the $\mathrm{Ru}$ center, the total backbonding effect from $\mathrm{Ru}$ to $\mathrm{L}$ is diminished, thus increasing the backbonding from $\mathrm{Ru}$ to the 2,2'-bpy ligand. This effect was not so evident in the series $[\mathrm{Ru}(\mathrm{bpy})(\mathrm{L})(\mathrm{trpy})]^{2+},{ }^{[12,13]}$ due to the complications in the spectra produced by the presence of a second chromophoric ligand (trpy).

\section{Electrochemistry}

Table 1 includes the values for the redox potentials of the $\mathrm{Ru}^{\mathrm{III}} / \mathrm{Ru}^{\mathrm{II}}$ and the bpy ${ }^{0 /-}$ couples present in the three complexes; the cyclic voltammogram for $\mathbf{1}$ is shown in the Supporting Information. The order disclosed by the MLCT bands is also shown in the decreasing values of $E_{1 / 2}\left(\mathrm{Ru}^{\mathrm{III}} /\right.$ $\mathrm{Ru}^{\mathrm{II}}$ ) redox potentials in the series: $\mathrm{pz}>4,4^{\prime}$-bpy $>$ bpe. The $\mathrm{Ru}^{\mathrm{II}}$ state is stabilized when the total $\pi$-backbonding effects are maximized. The reduction potentials, $E_{1 / 2}\left(\mathrm{bpy}^{0 /-}\right)$, of the ligand bpy are almost unchanged in this series.

\section{Photophysical Properties}

Figure 4 shows the emission spectrum of complex 3, which is the only complex of this series that emits at room temperature in $\mathrm{CH}_{3} \mathrm{CN}\left(\lambda_{\text {em }}=606 \mathrm{~nm}\right.$ at $\left.\lambda_{\text {exc }}=400 \mathrm{~nm}\right)$. This value is consistent with the photophysical data of $[\mathrm{Ru}(\mathrm{bpy})(\mathrm{py})(\mathrm{tpm})]^{2+}$ (py = pyridine).$^{[9]}$ Complexes $\mathbf{1}$ and 2 do not emit at room temperature and rearrange with loss of ligand $\mathrm{L}$ to give $\left[\mathrm{Ru}(\mathrm{bpy})\left(\mathrm{CH}_{3} \mathrm{CN}\right)(\mathrm{tpm})\right]^{2+}$ as the final product. We thus conclude that the dd states become lower in energy than the MLCT states when the absorption maximum corresponding to the $\mathrm{d}_{\pi}(\mathrm{Ru}) \rightarrow \pi^{*}$ (bpy) transition is lower than $400 \mathrm{~nm}$, with subsequent labilization of the ligand L. This result is consistent with that found before ${ }^{[9]}$ when changing the substituents $\mathrm{X}$ in complexes of the type $\left[\mathrm{Ru}(\mathrm{py})(\mathrm{tpm})\left(\mathrm{X}_{2} \text { bpy }\right)\right]^{2+}$; in this case, changing the nature of $\mathrm{X}$ exerts a coarse control over the energies of the $\mathrm{Ru} \rightarrow$ bpy MLCT excited states.

\section{Dinuclear Species}

Preliminary experiments indicated the formation of dinuclear species when reacting the mononuclear complexes described here with equimolar amounts of $\left[\mathrm{Ru}\left(\mathrm{NH}_{3}\right)_{5}\left(\mathrm{H}_{2} \mathrm{O}\right)\right]\left(\mathrm{PF}_{6}\right)_{2}$ under an $\mathrm{Ar}$ atmosphere. Oxidation of these new complexes with $\mathrm{Br}_{2}$ gave the corresponding mixed-valent complexes $[\mathrm{Ru}(\mathrm{bpy})(\mathrm{L})(\mathrm{tpm}) \mathrm{Ru}-$ $\left.\left(\mathrm{NH}_{3}\right)_{5}\right]^{5+}\left(\mathrm{L}=\mathrm{pz}, 4,4^{\prime}\right.$-bpy, and bpe $)$. They all show MMCT (metal-to-metal charge transfer) bands near $700 \mathrm{~nm}$, as expected because of the high redox asymmetry between both metallic centers. ${ }^{[26]}$ The properties of these species will be presented in a subsequent paper. ${ }^{[27]}$ There are no reports of mixed-valent complexes that include tpm in their coordination spheres.

\section{Conclusions}

The spectroscopic and electrochemical properties of the new complexes described in this work disclose the following order of decreasing energies of $\mathrm{Ru} \rightarrow$ bpy MLCT states: $[\mathrm{Ru}(\mathrm{bpy})(\mathrm{pz})(\mathrm{tpm})]^{2+}>\left[\mathrm{Ru}\left(4,4^{\prime} \text {-bpy)(bpy)(tpm) }\right]^{2+}>\right.$ $[\mathrm{Ru}(\mathrm{bpe})(\mathrm{bpy})(\mathrm{tpm})]^{2+}$. This can be accounted for by the decreasing $\pi$-backbonding effects along the series. While a coarse control of the energies of the MLCT states in com- 
Table 1. Electrochemical and absorption spectroscopic data of complexes of the type $[\mathrm{Ru}(\mathrm{bpy})(\mathrm{L})(\mathrm{tpm})]^{2+}$ in $\mathrm{CH}_{3} \mathrm{CN}$ at room temperature

\begin{tabular}{|c|c|c|c|c|}
\hline Complex ${ }^{[a]}$ & $E_{1 / 2}\left(\mathrm{Ru}^{\mathrm{III}} / \mathrm{Ru}^{\mathrm{II}}\right)^{[\mathrm{b}]}$ & $E_{1 / 2}\left(\mathrm{bpy}^{0 /-}\right)^{[\mathrm{b}]}$ & $\lambda_{\max }\left(10^{-3} \varepsilon\right)^{[\mathrm{c}]}$ & Assignment \\
\hline$[\mathrm{Ru}(\mathrm{bpy})(\mathrm{pz})(\mathrm{tpm})]^{2+}$ & 1.26 & -1.41 & $\begin{array}{l}457 \mathrm{sh}(2.0) \\
418 \mathrm{sh}(2.0) \\
392(8.4) \\
327(6.8) \\
294(19) \\
286(22) \\
254(15) \\
227(14) \\
210(24)\end{array}$ & $\begin{array}{l}d_{\pi \rightarrow \pi^{*}} \text { (bpy) } \\
d_{\pi \rightarrow \pi^{*}} \text { (pz) } \\
d_{\pi \rightarrow \pi^{*}} \text { (bpy) } \\
d_{\pi \rightarrow \pi^{*}} \text { (bpy) } \\
\pi \rightarrow \pi^{*} \\
\pi \rightarrow \pi^{*} \\
\pi \rightarrow \pi^{*} \\
\pi \rightarrow \pi^{*} \\
\pi \rightarrow \pi^{*}\end{array}$ \\
\hline$\left[\mathrm{Ru}\left(4,4^{\prime} \text {-bpy }\right)(\mathrm{bpy})(\mathrm{tpm})\right]^{2+}$ & 1.21 & -1.41 & $\begin{array}{l}464 \mathrm{sh}(2.3) \\
424 \mathrm{sh}(5.7) \\
395(11) \\
339(6.8) \\
290 \mathrm{sh}(17) \\
286(22) \\
254 \mathrm{sh}(19) \\
237(22) \\
210(26)\end{array}$ & $\begin{array}{l}d_{\pi} \rightarrow \pi^{*}(\text { bpy }) \\
d_{\pi} \rightarrow \pi^{*}\left(4,4^{\prime}-\text { bpy }\right) \\
d_{\pi} \rightarrow \pi^{*}(\text { bpy }) \\
d_{\pi \rightarrow \pi^{*}}(\text { bpy }) \\
\pi \rightarrow \pi^{*} \\
\pi \rightarrow \pi^{*} \\
\pi \rightarrow \pi^{*} \\
\pi \rightarrow \pi^{*} \\
\pi \rightarrow \pi^{*}\end{array}$ \\
\hline$[\mathrm{Ru}(\mathrm{bpe})(\mathrm{bpy})(\mathrm{tpm})]^{2+}$ & 1.15 & -1.39 & $\begin{array}{l}466 \mathrm{sh}(4.6) \\
426 \mathrm{sh}(4.6) \\
410(13) \\
343 \mathrm{sh}(6.7) \\
294 \mathrm{sh}(32) \\
285(35) \\
254(27)\end{array}$ & $\begin{array}{l}\mathrm{d}_{\pi} \rightarrow \pi^{*} \text { (bpy) } \\
\mathrm{d}_{\pi \rightarrow \pi^{*}} \text { (bpe) } \\
\mathrm{d}_{\pi \rightarrow \pi^{*}} \text { (bpy) } \\
\mathrm{d}_{\pi \rightarrow \pi^{*}} \text { (bpy) } \\
\pi \rightarrow \pi^{*} \\
\pi \rightarrow \pi^{*} \\
\pi \rightarrow \pi^{*}\end{array}$ \\
\hline$[\mathrm{Ru}(\mathrm{bpy})(\mathrm{py})(\mathrm{tpm})]^{2+}[\mathrm{d}]$ & 1.15 & -1.39 & $\begin{array}{l}466 \text { sh }(1.8) \\
416 \text { sh }(4.2) \\
343 \text { sh }(12.5) \\
287(26) \\
244(15)\end{array}$ & $\begin{array}{l}\mathrm{d}_{\pi} \rightarrow \pi^{*} \text { (bpy) } \\
\mathrm{d}_{\pi} \rightarrow \pi^{*} \text { (bpy) } \\
\mathrm{d}_{\pi \rightarrow \pi^{*}} \text { (bpy) } \\
\pi \rightarrow \pi^{*} \\
\pi \rightarrow \pi^{*}\end{array}$ \\
\hline
\end{tabular}

${ }^{[a]}$ As their $\mathrm{PF}_{6}{ }^{-}$salts. ${ }^{[\mathrm{b}]} \mathrm{V}$ vs. SCCE, with $0.1 \mathrm{M} \mathrm{TBAH}$ as supporting electrolyte. ${ }^{[\mathrm{c}]} \lambda_{\max }$ in nm, $\varepsilon$ values in $\mathrm{M}^{-1} \cdot \mathrm{cm}^{-1}$. ${ }^{[\mathrm{d}]}$ From ref. $^{[2]}$

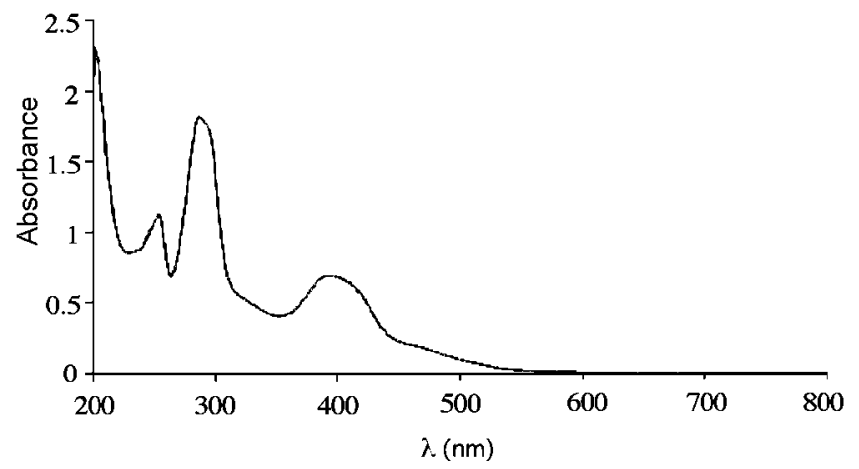

Figure 3. UV/Vis spectrum of $[\mathrm{Ru}(\mathrm{bpy})(\mathrm{pz})(\mathrm{tpm})]^{2+}$ in $\mathrm{CH}_{3} \mathrm{CN}$ at room temperature $\left(C=9.5 \times 10^{-5} \mathrm{M}\right)$

plexes of the type $\left[\mathrm{Ru}(\mathrm{py})(\mathrm{tpm})\left(\mathrm{X}_{2} \mathrm{bpy}\right)\right]^{2+}$ has been reported ${ }^{[9]}$ by changing the nature of the substituents $\mathrm{X}$ on the 2,2'-bipyridine unit, a much finer control can be exerted by changing the $\pi$-backbonding abilities of the ligand $\mathrm{L}$. Therefore, a whole range of Ru-bpy excited states can be finally obtained, which is relevant for the development of efficient photocatalysts. ${ }^{[18]}$ Furthermore, these mononuclear species are useful building blocks for new mixed-valent

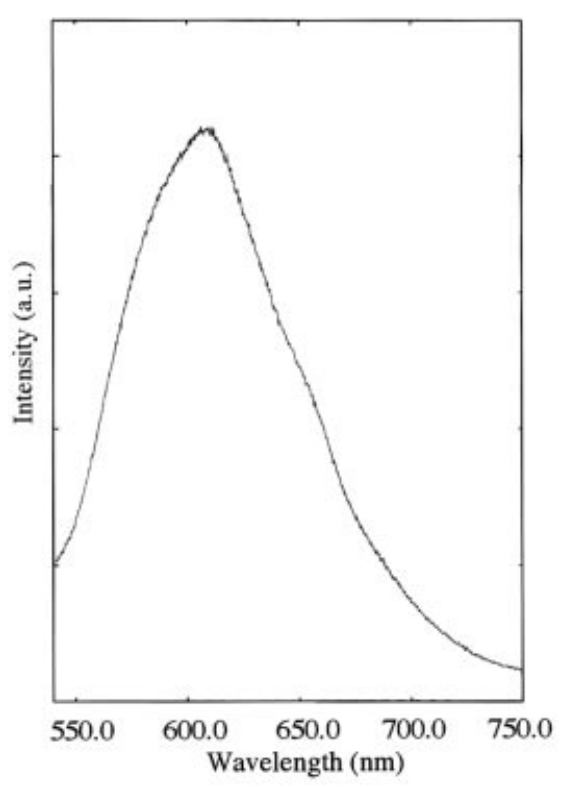

Figure 4. Emission spectrum, at room temperature, of $[\mathrm{Ru}(\mathrm{bpy})(\mathrm{bpe})(\mathrm{tpm})]^{2+}$ in $\mathrm{CH}_{3} \mathrm{CN}\left(\lambda_{\mathrm{exc}}=400 \mathrm{~nm}\right)$ 
species that incorporate tpm in their coordination spheres. ${ }^{[27]}$

\section{Experimental Section}

Materials: All reagents were obtained from Aldrich Chemical Co. and used without further purification. $\mathrm{CH}_{3} \mathrm{CN}$ was freshly distilled for electrochemical measurements.

Preparations: All synthetic manipulations were routinely performed under nitrogen using Schlenk tubes and vacuum-line techniques. Electrochemical experiments were performed in the dark under $\mathrm{N}_{2}$ or Ar with degassed solvents. IR spectra were recorded with an FT Nicolet 205 spectrophotometer with a reflectance accessory. UV/ Vis spectra were recorded with a Cary 50 Scan (Varian) spectrophotometer, with $1-\mathrm{cm}$ quartz cells. Cyclic voltammetry (CV) measurements were carried out with an IJ-Cambria IH-660 equipment with a three-electrode cell. A glassy carbon disk electrode (3 mm diameter) from BAS was used as working electrode, platinum wire as auxiliary electrode, and SSCE as reference electrode. All CV experiments were recorded at a $200 \mathrm{mV} \cdot \mathrm{s}^{-1}$ scan rate under nitrogen purging, in pure $\mathrm{CH}_{3} \mathrm{CN}$ containing $0.1 \mathrm{M}$ tetrakis(n-butyl)ammonium hexafluorophosphate (TBAH). The values for the redox potentials, $E_{1 / 2}$, were estimated from cyclic voltammetry as the average of oxidative and reductive peak potentials $\left(E_{\mathrm{p}, \mathrm{a}}+E_{\mathrm{p}, \mathrm{c}}\right) / 2$. NMR spectra were recorded in $\mathrm{CD}_{3} \mathrm{CN}$ with a Bruker $500 \mathrm{MHz}$ spectrometer. Elemental analyses were carried out using a CHNSO Elemental Analyser EA-1108 from Fisons. Luminiscence spectra were recorded with a Shimadzu RF-5301 PC spectrofluorometer, provided with $1-\mathrm{cm}$ fluorescence cells. Argon was bubbled through the solutions prior to the photophysical measurements.

Synthesis of $[\mathbf{R u}(\mathrm{tpm})(\mathrm{bpy})(\mathbf{p z})]\left(\mathrm{PF}_{\mathbf{6}}\right)_{2} \quad$ (1): A sample of $[\mathrm{RuCl}(\mathrm{bpy})(\mathrm{tpm})] \mathrm{Cl} \cdot 2 \mathrm{H}_{2} \mathrm{O}(80 \mathrm{mg}, 0.14 \mathrm{mmol})$, prepared as described before, ${ }^{[8]}$ was added to a solution of pz $(0.6 \mathrm{~g}, 7 \mathrm{mmol})$ in ethanol/water $(1: 1,25 \mathrm{~mL})$ and the mixture heated at reflux for $6 \mathrm{~h}$. After cooling, the ethanol was evaporated and the remaining aqueous solution was loaded onto a Sephadex C-25 column. The unchanged chloro complex was eluted with $0.2 \mathrm{M} \mathrm{LiCl}$, while the pz complex was eluted with $0.3 \mathrm{M} \mathrm{LiCl}$. This last eluate was concentrated to $5 \mathrm{~mL}$ and then a concentrated solution of $\mathrm{NH}_{4} \mathrm{PF}_{6}(1 \mathrm{~g}$ in $2 \mathrm{~mL}$ of water) was added. After cooling, the precipitate was filtered and washed with cold water. It was then redissolved in acetone $(5 \mathrm{~mL})$, re-precipitated with diethyl ether $(50 \mathrm{~mL})$, washed with diethyl ether, and dried in vacuo over $\mathrm{KOH}$. Yield: $38 \mathrm{mg}$ (32\%). $\mathrm{C}_{24} \mathrm{H}_{22} \mathrm{~F}_{12} \mathrm{~N}_{10} \mathrm{P}_{2} \mathrm{Ru}$ (841.07): calcd. C 34.30, H 2.63, N 16.60; found $\mathrm{C} 34.20, \mathrm{H} 2.70, \mathrm{~N} 16.20 .{ }^{1} \mathrm{H} \mathrm{NMR}(500 \mathrm{MHz}$, $\left.\mathrm{CD}_{3} \mathrm{CN}, 25{ }^{\circ} \mathrm{C}\right): \delta=6.32(\mathrm{dd}, 1 \mathrm{H}, \mathrm{H} 9), 6.60\left(\mathrm{~d}, 1 \mathrm{H}, J_{10-9}=\right.$ $2.3 \mathrm{~Hz}, \mathrm{H} 10$ ), 6.78 (dd, $2 \mathrm{H}, \mathrm{H} 2$ ), 7.56 (dd, $2 \mathrm{H}, \mathrm{H} 14), 7.56$ (d, 2 H, HA), $7.96\left(\mathrm{~d}, J_{3-2}=2.1 \mathrm{~Hz}, 2 \mathrm{H}, \mathrm{H} 3\right), 8.24$ (dd, $\left.2 \mathrm{H}, \mathrm{H} 13\right)$, $8.26(\mathrm{dd}, 2 \mathrm{H}, \mathrm{HB}), 8.40\left(\mathrm{~d}, J_{8,9}=2.9 \mathrm{~Hz}, 1 \mathrm{H}, \mathrm{H} 8\right), 8.57\left(\mathrm{~d}, J_{1,2}=\right.$ $3.0 \mathrm{~Hz}, 2 \mathrm{H}, \mathrm{H} 1$ ), 8.60 (br. d, $J_{15,14}=5.4 \mathrm{~Hz}, 2 \mathrm{H}, \mathrm{H} 15$ ), 8.78 (br. $\left.\mathrm{d}, J_{12,13}=8.1 \mathrm{~Hz}, 2 \mathrm{H}, \mathrm{H} 12\right), 9.18(\mathrm{~s}, 1 \mathrm{H}, \mathrm{H} 4), \mathrm{ppm} \cdot{ }^{13} \mathrm{C} \mathrm{NMR}$ (500 MHz, $\mathrm{CD}_{3} \mathrm{CN}, 25^{\circ} \mathrm{C}$ ): $\delta=76.0$ (C4), 108.8 (C9), 110.3 (C2), 125.6 (C12), 126.5 (C14), 135.8 (C8), 135.9 (C1), 138.6 (C13), 144.3 (C10), 145.5 (CB), 147.4 (C3), 148.5 (CA), 153 (C15) ppm. NOEs: $\mathrm{H} 4$ with $\mathrm{H} 1$ and $\mathrm{H} 8$; $\mathrm{H} 3$ with $\mathrm{H} 15$.

Synthesis of $\left[\mathrm{Ru}\left(4,4^{\prime}-\mathrm{bpy}\right)(\mathrm{bpy})(\mathrm{tpm})\right]\left(\mathrm{PF}_{6}\right)_{2} \cdot \mathbf{2 H}_{\mathbf{2}} \mathbf{0}$ (2): A sample of $[\mathrm{RuCl}(\mathrm{bpy})(\mathrm{tpm})] \mathrm{Cl} \cdot 2 \mathrm{H}_{2} \mathrm{O}(70 \mathrm{mg}, 0.12 \mathrm{mmol})$ was added to a solution of 4,4'-bpy (1 g, $6.4 \mathrm{mmol})$ in ethanol/water $(1: 1,25 \mathrm{~mL})$ and the mixture heated at reflux for $6 \mathrm{~h}$. After cooling, the ethanol was evaporated and the remaining aqueous solution was filtered to eliminate excess $4,4^{\prime}$-bpy. The filtrate was loaded onto a Sephadex C-25 column. The unchanged chloro complex was eluted with 0.2 M $\mathrm{LiCl}$, while the 4,4'-bpy complex was eluted with $0.3 \mathrm{M} \mathrm{LiCl}$. This last eluate was concentrated to $5 \mathrm{~mL}$ and then a concentrated solution of $\mathrm{NH}_{4} \mathrm{PF}_{6}(1 \mathrm{~g}$ in $2 \mathrm{~mL}$ of water) was added. After cooling, the precipitate was filtered, washed thoroughly with cold water, dried in vacuo over $\mathrm{KOH}$, and recrystallized from acetone/diethyl ether. Yield: $37 \mathrm{mg}(33 \%) . \mathrm{C}_{30} \mathrm{H}_{30} \mathrm{~N}_{10} \mathrm{O}_{2} \mathrm{P}_{2} \mathrm{~F}_{12} \mathrm{Ru}$ (953.07): calcd. $\mathrm{C}$ 37.8, H 3.2, N 14.7; found $\mathrm{C} 38.1, \mathrm{H} \mathrm{2.7,} \mathrm{N} \mathrm{14.1.}{ }^{1} \mathrm{H} \mathrm{NMR}$ $\left(500 \mathrm{MHz}, \mathrm{CD}_{3} \mathrm{CN}, 25^{\circ} \mathrm{C}\right): \delta=6.30(\mathrm{dd}, 1 \mathrm{H}, \mathrm{H} 9), 6.58\left(\mathrm{~d}, J_{9,10}=\right.$ $2.2 \mathrm{~Hz}, 1 \mathrm{H}, \mathrm{H} 10), 7.47$ (dd, $2 \mathrm{H}, \mathrm{HB}), 7.55$ (dd, $2 \mathrm{H}, \mathrm{H} 14), 7.64$ $\left(\mathrm{dd}, J_{\mathrm{A}, \mathrm{B}}=5.7, J_{\mathrm{A}, \mathrm{D}}=1.3 \mathrm{~Hz}, 2 \mathrm{H}, \mathrm{HA}\right), 7.82\left(\mathrm{dd}, J_{\mathrm{C}, \mathrm{D}}=5.1\right.$, $\left.J_{\mathrm{C}, \mathrm{B}}=1.4 \mathrm{~Hz}, 2 \mathrm{H}, \mathrm{HC}\right), 7.95\left(\mathrm{~d}, J_{3,2}=1.9 \mathrm{~Hz}, 2 \mathrm{H}, \mathrm{H} 3\right), 8.22$ $\left(\mathrm{ddd}, J_{12,14}=8.5, J_{12,13}=7.7 \mathrm{~Hz}, 2 \mathrm{H}, \mathrm{H} 13\right), 8.63\left(\mathrm{~d}, J_{8,9}=2.8 \mathrm{~Hz}\right.$, $1 \mathrm{H}, \mathrm{H} 8), 8.67\left(\mathrm{dd}, J_{15,14}=5.6, J_{15,13}=1.2 \mathrm{~Hz}, 2 \mathrm{H}, \mathrm{H} 15\right), 8.73$ $\left(\mathrm{dd}, J_{\mathrm{D}, \mathrm{C}}=5.1, J_{\mathrm{D}, \mathrm{A}}=1.3 \mathrm{~Hz}, 2 \mathrm{H}, \mathrm{HD}\right), 8.79\left(\mathrm{~d}, J_{12,13}=7.7 \mathrm{~Hz}\right.$, $2 \mathrm{H}, \mathrm{H} 12), 8.86$ (d, $\left.J_{1,2}=2.6 \mathrm{~Hz}, 2 \mathrm{H}, \mathrm{H} 1\right), 10.96(\mathrm{~s}, 1 \mathrm{H}, \mathrm{H} 4)$ ppm. ${ }^{13} \mathrm{C}$ NMR $\left(500 \mathrm{MHz} \mathrm{CD}_{3} \mathrm{CN}, 25{ }^{\circ} \mathrm{C}\right): \delta=74.9$ (C4), 108.8 (C9), 110(C2), 122.8 (CC), 125.5 (C12), 126.8 (C14), 135.7 (C8), 136 (C1), 138.3 (C13), 144 (C10), 147.6 (C3, CD), 153.6 (C15), 154.2 (CA) ppm. NOEs: H4 with H1 and H8; H3 with H15 and HA.

Synthesis of $[\mathrm{Ru}(\mathrm{bpe})(\mathrm{bpy})(\mathrm{tpm})]\left(\mathrm{PF}_{6}\right)_{2}\left(\mathrm{CH}_{3}\right)_{2} \mathrm{CO}$ (3): A sample of $[\mathrm{RuCl}(\mathrm{bpy})(\mathrm{tpm})] \mathrm{Cl} \cdot 2 \mathrm{H}_{2} \mathrm{O}(100 \mathrm{mg}, 0.17 \mathrm{mmol})$ was added to a solution of bpe $(0.6 \mathrm{~g}, 3.3 \mathrm{mmol})$ in ethanol/water $(1: 1,25 \mathrm{~mL})$ and the mixture heated at reflux for $6 \mathrm{~h}$. After cooling, the ethanol was evaporated and the remaining aqueous solution was filtered to eliminate excess bpe. The filtrate was loaded onto a Sephadex C25 column. The unchanged chloro complex was eluted with $0.2 \mathrm{M}$ $\mathrm{LiCl}$, while the bpe complex was eluted with $0.3 \mathrm{M} \mathrm{LiCl}$. This last eluate was concentrated to $5 \mathrm{~mL}$ and then a concentrated solution of $\mathrm{NH}_{4} \mathrm{PF}_{6}(1 \mathrm{~g}$ in $2 \mathrm{~mL}$ of water) was added. After cooling, the precipitate was filtered, washed thoroughly with cold water, dried in vacuo over $\mathrm{KOH}$, and then recrystallized from acetone/diethyl ether. Yield: $29 \mathrm{mg}(33 \%) . \mathrm{C}_{35} \mathrm{H}_{34} \mathrm{~F}_{12} \mathrm{~N}_{10} \mathrm{OP}_{2} \mathrm{Ru}$ (1001.1): calcd. $\mathrm{C}$ 42.0, H 3.4, N 14.0; found $\mathrm{C} 42.1, \mathrm{H} 3.0, \mathrm{~N}$ 13.6. ${ }^{1} \mathrm{H} \mathrm{NMR}$ $\left(500 \mathrm{MHz}, \mathrm{CD}_{3} \mathrm{CN}, 25^{\circ} \mathrm{C}\right): \delta=6.31(\mathrm{dd}, 1 \mathrm{H}, \mathrm{H} 9), 6.59(\mathrm{~d}, 1 \mathrm{H}$, H10), 6.77 (dd, 2 H, H2), 7.30 (d, 2 H, HB), 7.40(d, 1 H, HE), 7.49 (d, 2 H, H15), 7.50 (d, 1 H, HF), 7.55 (dd, 2 H, H14), 7.80 (d, $\left.J_{\mathrm{C}, \mathrm{D}}=5.8 \mathrm{~Hz}, 2 \mathrm{H}, \mathrm{HC}\right), 7.96(\mathrm{~d}, 2 \mathrm{H}, \mathrm{H} 3), 8.22$ (ddd, $\left.2 \mathrm{H}, \mathrm{H} 13\right)$, 8.40 (d, 1 H, H8), 8.58 (d, 2 H, H1), 8.65 (dd, 2 H, H15), 8.78 (d, $2 \mathrm{H}, \mathrm{H} 12), 9.18$ (s, $1 \mathrm{H}, \mathrm{H} 4) \mathrm{ppm} .{ }^{13} \mathrm{C}$ NMR $\left(500 \mathrm{MHz}, \mathrm{CD}_{3} \mathrm{CN}\right.$, $\left.25^{\circ} \mathrm{C}\right): \delta=76.3(\mathrm{C} 4), 108.8$ (C9), 110.1 (C2), 122.7 (CB), 123.2 (C13), 125.3 (C12), 126.7 (C14), 130.9 (CE), 133 (CF), 135.8 (C8), 136 (C1), 138.2 (C13), 144.2 (C10), 145.4 (CD), 147.7 (C3), 153.2 (C15), 153.7(CA) ppm. NOEs: H4 with $\mathrm{H} 1$ and H8; H3 with H8 and HA.

X-ray Structure Determination for 1: Yellow, needle-shaped crystals of 1 were grown by slow diffusion of diethyl ether into a concentrated acetone solution of the complex at room temperature. The crystal to be measured $(700 \times 40 \times 20 \mu \mathrm{m})$ was isolated under inert conditions and immersed in perfluoropolyether as protection. Empirical formula $\mathrm{C}_{24} \mathrm{H}_{22} \mathrm{~F}_{12} \mathrm{~N}_{10} \mathrm{P}_{2} \mathrm{Ru}, M=841.53$, monoclinic, space group $P 2_{1}, a=10.3101(7) \AA, b=14.5022(10) \AA, c=$ 11.1954(7) $\AA$, $\beta=117.021(2)^{\circ}, V=1491.20(17) \AA^{3}, Z=2, \mu=$ $0.746 \mathrm{~mm}^{-1}, d_{\text {calcd. }}=1.874 \mathrm{~g} / \mathrm{cm}^{3}$. The measurement was carried out with a Siemens P4 diffractometer equipped with a SMARTCCD-1000 area detector, a MACScience Co. rotating anode with Mo- $K_{\alpha}$ radiation, a graphite monochromator and a Siemens lowtemperature device LT2 $\left(T=-120^{\circ} \mathrm{C}\right)$. The measurement range was $2.04-31.52^{\circ} ; 23212$ reflections were collected of which 9439 were unique $\left(R_{\text {int }}=0.0574\right)$ and 8449 observed $\left[F>4 \sigma\left(F_{\mathrm{o}}\right)\right]$. Full- 
sphere data collection $\omega$ and $\varphi$ scans. Programs used: Data collection Smart V. 5.060 (Bruker AXS, 1999), data reduction Saint+ Version 6.02 (Bruker AXS, 1999) and absorption correction SADABS (max/min transmission: 1.000000/0.490397, Bruker AXS, 1999). Structure solution and refinement were performed using SHELXTL Version 5.10 (Sheldrick, Universtität Göttingen, Göttingen, Germany, 1998). The structure was solved by direct methods and refined by full-matrix least-squares against $F^{2}$. All calculated hydrogen positions were refined as constrained. Final $\mathrm{R}_{1}$ $[I>2 \sigma(I)]=0.0449$ and $w \mathrm{R}\left(\mathrm{F}^{2}\right)[I>2 \sigma(I)]=0.1045$. The number of refined parameters was 564. Absolute structure parameter $-0.03(2)$. CCDC-230222 contains the supplementary crystallographic data for this paper. These data can be obtained free of charge at www.ccdc.cam.ac.uk/conts/retrieving.html [or from the Cambridge Crystallographic Data Centre, 12 Union Road, Cambridge CB2 1EZ, UK; Fax: + 44-1223-336-033; E-mail: deposit@ccdc.cam.ac.uk].

Supporting Information Available: Additional spectroscopic and electrochemical data (see also footnote on the first page of this article).

\section{Acknowledgments}

We thank the "Ministerio de Educación, Cultura y Deporte" of Spain for a fellowship awarded to N. E. K. We also thank CIUNT ("Consejo de Investigaciones de la Universidad Nacional de Tucumán”) and CONICET for financial support. N. E. K. is a Member of the Research Career of CONICET ("Consejo Nacional de Investigaciones Científicas y Técnicas”) Argentina. This research has also been financed by MCYT of Spain through projects BQU20000458, BQU2003-02884, and BQU2003-01677. We would also like to thank the CIRIT Generalitat de Catalunya (Spain) for a Distinction award and the aid SGR2001-UG-291.

[1] [1a] Organic and Inorganic Photochemistry (Eds.: V. Ramamurthy, K. S. Schanze), Marcel Dekker, New York, 1998. ${ }^{[1 b]}$ D. W. Thompson, J. R. Schoonover, D. K. Graff, C. N. Fleming, T. J. Meyer, J. Photochem. Photobiol. A: Chem. 2000, 137, 131-134. ${ }^{[1 \mathrm{c}]}$ H. E. Toma, R. M. Serrasqueiro, R. C. Rocha, G. J. F. Demets, H. Winnischofer, K. Araki, P. E. A. Ribeiro, C. L. Donnici, J. Photochem. Photobiol. A: Chem. 2000, 135, 185-191. ${ }^{[1 \mathrm{~d}]}$ M. H. Keefe, K. D. Benkstein, J. T. Hupp, Coord. Chem. Rev. 2000, 205, 201-228. ${ }^{[1 \mathrm{e}]}$ M. I. Romero, M. Rodríguez, A. Llobet, M. N. Collomb-Dunand-Sauthier, A. Deronzier, T. Parella, H. Stoeckli-Evans, J. Chem. Soc., Dalton Trans. 2000, 1689-1694. ${ }^{[1 \mathrm{ff}]}$ D. S. Tyson, C. R. Luman, X. Zhou, F. N. Castellano, Inorg. Chem. 2001, 40, 4063-4071. [1g] V. Balzani, A. Juris, Coord. Chem. Rev. 2001, 211, 97-115. ${ }^{[1 \mathrm{~h}]}$ D. M Dattelbaum, C. M. Hartshorn, T. J. Meyer, J. Am. Chem. Soc. 2002, 124, 4938-4939. [1i] S. Nikolau, H. E. Toma, J. Chem. Soc., Dalton Trans. 2002, 352-359.

[2] [2a] A. Hatzidimitriou, A. Gourdon, J. Devillers, J. P. Launay, E. Mena, E. Amouyal, Inorg. Chem. 1996, 35, 2212-2219. [2b] V. Balzani, A. Credi, M. Venturi, Chem. Eur. J. 2002, 8, $5524-5532 .{ }^{[2 c]}$ S. G. Camera, H. E. Toma, J. Photochem. Photobiol. A: Chem. 2002, 151, 57-65.

[3] [3a] J. P. Sauvage, J. P. Collin, J. C. Chambron, S. Guillerez, C. Coudret, Chem. Rev. 1994, 94, 993-1019. ${ }^{[3 b]}$ M. K. Brennaman, J. H. Alstrumacevedo, C. N. Fleming, P. Jang, T. J. Meyer, J. M. Papanikolas, J. Am. Chem. Soc. 2002, 124, 15094-15098.

${ }^{[4]}{ }^{[4 a]}$ A. E. Friedman, J. C. Cambrón, J. P. Sauvague, N. J. Turro, J. K. Barton, J. Am. Chem. Soc. 1990, 112, 4960-4962. ${ }^{[4 \mathrm{~b}]} \mathrm{Y}$. Jenkis, A. E. Friedman, N. J. Turro, J. K. Barton, Biochemistry 1992, 21, 809-816. ${ }^{[4 c]}$ R. E. Holmlin, E. D. A. Stemp, J. K.
Barton, Inorg. Chem. 1998, 37, 29-34. ${ }^{[4 \mathrm{~d}]} \mathrm{L}$. Li, H. Szmacinski, J. R. Lakowicz, Biospectroscopy 1997, 3, 155-159. ${ }^{[4 \mathrm{e}]} \mathrm{L}$. Li, H. Szmacinski, J. R. Lakowicz, Anal. Biochem. 1997, 244, 80-85. ${ }^{[4 \mathrm{f}]}$ E. Terpetschnig, H. Szmacinski, J. R. Lakowicz, Anal. Biochem. 1995, 227, $140-147 .{ }^{[4 \mathrm{~g}]} \mathrm{H}$. Youn, E. Terpetschnig, H. Szmacinski, J. R. Lakowicz, Anal. Biochem. 1995, 232, 24-30. ${ }^{[4 \mathrm{~h}]}$ Z. Murtaza, Q. Chang, G. Rao, H. Lin, J. R. Lakowicz, Anal. Biochem. 1997, 247, 216-222. [4i] T. M. Santos, B. J. Goodfellow, M. G. B. Drew, J. Pedrosa de Jesus, V. Félix, Metal-Based Drugs 2001, 8, 125-136.

[5] [5a] J. P. Sauvage, Acc. Chem. Res. 1998, 31, 611-619. [5b] V. Balzani, M. Gomez-López, J. F. Stoddart, Acc. Chem. Res. 1998, 31, 405-414. [5c] Struct. Bonding (Berlin) 2001, 99, 1-281: Special volume on "Molecular Machines and Motors". [5d] V. Balzani, A. Credi, F. M. Raymo, J. F. Stoddart, Angew. Chem. Int. Ed. 2000, 39, 3349-3391. [5e] J. P. Collin, C. Dietrich-Buchecker, P. Gaviña, M. C. Jiménez-Molero, J. P. Sauvage, Acc. Chem. Res. 2001, 34, 477-487.

${ }^{[6]}{ }^{[6 a]}$ B. P. Sullivan, J. M. Calvert, T. J. Meyer, Inorg. Chem. 1980 , 19, 1404-1407. ${ }^{[6 b]}$ M. Silva, E. Tfouni, Inorg. Chem. 1997, 36, 274-277. ${ }^{[6 c]}$ G. Malouf, P. C. Ford, J. Am. Chem. Soc. 1977, 26, 7213-7221. [6d] A. C. Laemmel, J. P. Collin, J. P. Sauvage, R. Acad. Sci. Paris, Sér. IIc, Chim./Chem. 2000, 3, 43-49. ${ }^{[6 e]}$ T. Matsubara, C. J. Creutz, Am. Chem. Soc. 1979, 18, 1956-1966.

[7] [7a] R. Arakawa, K. Abe, T. Abura, Y. Nakabayashi, Bull. Chem. Soc. Jpn. 2002, 75, 1983-1989. ${ }^{[7 b]}$ C. A. Bessel, J. A. Margarucci, J. H. Acquaye, R. S. Rubino, J. Crandall, A. J. Jircitano, K. J. Takeuchi, Inorg. Chem. 1993, 32, 5779-5784.

${ }^{[8]}$ A. Llobet, P. Doppelt, T. J. Meyer, Inorg. Chem. 1988, 27 , $514-520$

[9] K. R. Barqawi, A. Llobet, T. J. Meyer, J. Am. Chem. Soc. 1988, 110, 7751-7759.

${ }^{[10]}$ P. A. Anderson, F. R. Keene, T. J. Meyer, J. A. Moss, G. F. Strouse, J. A. Treadway, J. Chem. Soc., Dalton Trans. 2002, 20, 3820-3831.

${ }^{[11]}$ A. Llobet, Inorg. Chim. Acta 1994, 221, 125-131.

${ }^{[12]}$ F. Fagalde, N. E. Katz, J. Chem. Soc., Dalton Trans. 1993, $571-575$.

${ }^{[13]}$ F. Fagalde, N. E. Katz, Polyhedron 1995, 14, 1213-1220.

${ }^{[14]}$ D. Szalda, F. Fagalde, N. E. Katz, Acta Crystallogr., Sect. C 1996, 52, 3013-3016.

${ }^{[15]}$ M. E. García Posse, M. M. Vergara, F. Fagalde, N. E. Katz, Polyhedron 2003, 22, 465-471.

${ }^{[16]}$ N. C. Fletcher, F. R. Keene, J. Chem. Soc., Dalton Trans. 1998, 14, 2293-2302.

${ }^{[17]}$ F. Laurent, E. Plantalech, B. Donnadieu, A. Jiménez, F. Hernández, M. Martínez-Ripoll, M. Biner, A. Llobet, Polyhedron 1999, 18, 3321-3331.

${ }^{[18]}$ N. Sutin, C. Creutz, Pure Appl. Chem. 1980, 52, 2717-2738.

${ }^{[19]}$ T. J. Meyer, Acc. Chem. Res. 1989, 22, 163-170.

${ }^{[20]}$ V. Balzani, F. Scandola, Supramolecular Photochemistry, Ellis Horwood, Chichester, 1991.

${ }^{[21]}$ V. Balzani, A. Juris, M. Venturi, S. Campagna, S. Serroni, Chem. Rev. 1996, 96, 759-834.

${ }^{[22]}$ V. Balzani, S. Campagna, G. Denti, A. Juris, S. Serroni, M. Venturi, Acc. Chem. Res. 1998, 31, 26-34.

${ }^{[23]}$ L. Huang, K. J. Seward, B. P. Sullivan, W. E. Jones, J. J. Mecholsky, W. J. Dressick, Inorg. Chim. Acta 2000, 310, 227-236.

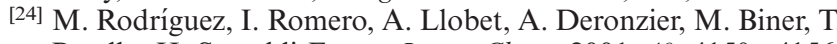
Parella, H. Stoeckli-Evans, Inorg. Chem. 2001, 40, 4150-4156.

${ }^{[25]}$ C. Sens, M. Rodríguez, I. Romero, A. Llobet, T. Parella, J. Benet-Buchholz, Inorg. Chem. 2003, 42, 8385-8394.

${ }^{[26]}$ N. E. Katz, C. Creutz, N. Sutin, Inorg. Chem. 1988, 27, $1687-1694$

${ }^{[27]}$ N. E. Katz, F. Fagalde, M. I. Romero, A. Llobet, work in progress.

Received June 8, 2004 Early View Article

Published Online November 18, 2004 